\title{
Occurrence of ticks (Acari: Ixodidae) on human hosts, in three municipalities in the State of Pará, Brazil
}

\author{
Parasitismo por carrapatos (Acari: Ixodidae) em humanos, em três municípios do Estado do Pará \\ Nicolau Maués Serra-Freire ${ }^{1 *}$
}

${ }^{1}$ Laboratory of Ixodides, National Reference for Rickettsia Vectors, LIRN-IOC/Fiocruz

Received October 6, 2009

Accepted July 15, 2010

\begin{abstract}
Assuming the existence of tick parasitism in humans in the State of Pará, an aggregate observational study was developed along a transversal line in three cities of the State, during two years. Interviews and examinations of 2,160 townspeople and tourists were carried out, without discrimination of ethnic, sex, age, or social status, and classified for effects analyzed for four bands of age, six types of activities in the society, and two sexes. Larvae, nymphs, and adults of ticks had been identified with cases of parasitism involving six species, of the genus Amblyomma, the genus Ixodes, Rhipicephalus sanguineus, Anocentor nitens, and Ornithodorus talaje (the first case registered in Pará), infecting human beings. Adults and agricultural workers were most frequently attacked, followed by students. A. cajennense and $R$. sanguineus are the species most frequent in the parasitism affecting humans, and $A$. cajennense is the dominant species. The statistical prevalence was largest in Cachoeira do Arari, Ilha do Marajó. In Santarém the greatest average intensity of parasitism was for $R$. sanguineus, and in the other locations it wasfor $A$. cajennense. Agricultural workers faced the greatest risk from parasitism, and to place in practice elementary measures of prevention would reduce by $25 \%$ the number of cases.
\end{abstract}

Keywords: Ixodidae on human beings, Cachoeira do Arari, Marajó Island, Santarém, Paragominas city.

\section{Resumo}

Com a hipótese de parasitismo por carrapatos em humanos no Estado do Pará, foi desenvolvido estudo observacional, agregado, transversal em três mesoregiôes do Estado, durante dois anos. Foram entrevistados e examinados 2.160 munícipes, e turistas, sem discriminação étnica, de sexo, idade, e social, classificados para efeito de análises em quatro faixas de idade, seis tipos de atividades na sociedade, e dois sexos. Houve casos de parasitismo por larvas, ninfas, e adultos de carrapatos, envolvendo seis espécies do gênero Amblyomma, o gênero Ixodes, Rhipicephalus sanguineus, Anocentor nitens e Ornithodorus talaje (primeiro registo para o Estado). Adultos e os trabalhadores rurais são os mais atacados, seguidos dos estudantes. A. cajennense e $R$. sanguineus são as espécies mais freqüentes no parasitismo de humano, e $A$. cajennense é a espécie dominante. A prevalência foi superior a $40 \%$ nos três municípios, e estatisticamente maior em Cachoeira do Arari, Ilha de Marajó. Em Santarém R. sanguineus teve a maior intensidade média de parasitismo, nos outros municípios foi por $A$. cajennense. Estar em atividade rural dobra o risco do parasitismo, e o esclarecimento da população, para colocar em prática medidas elementares de prevenção reduziria em $25 \%$ o número de casos.

Palavras-chave: Ixodidae em seres humanos, Cachoeira do Arari, Ilha de Marajó, Santarém, município de Paragominas.

\section{Introduction}

To this day, known diseases with agents transmitted by ticks comprise an extensive set. Despite the older concept that they would be limited to certain regions, although being characteristically focal, such diseases have been found in almost every place they were studied.

\footnotetext{
${ }^{*}$ Corresponding author: Nicolau Maués Serra-Freire

Laboratory of Ixodides, National Reference for Rickettsia Vectors,

LIRN-IOC/Fiocruz, Av. Brasil 4365, CEP 21040-900,

Manguinhos - RJ, Brazil;

e-mail: nmsf@ioc.fiocruz.br
}

Human diseases with agents transmitted by ticks in Brazil include: rickettsia (Rocky Mountain spotted fever), spirochetes (Lyme disease, tick-borne relapsing fever), and protozoans, such as the one for babesiosis (KJEMTRUP; CONRAD, 2000).

Ticks are arthropodes in the Class Arachnida, subclass Acari, and all are ectoparasites of vertebrates. Of the 850 species considered viable in the world, about 680 are part of the Ixodidae family, and 170 of the Argasidae family, and can be considered as reservoirs, perpetuating the transmission power of the agents for its progeny, by transovarial and/or transstadial means. 
The diseases that involve ticks for transmission usually have a focal distribution, since the mobility of vector is restricted, except when transported by vertebrates, and even then many species have a limited capacity to adapt to the urban milieu. These diseases whose only vector is the tick normally do not occur in rapid progression outbreaks or epidemics, because the vectors are eventual human ectoparasites, and in general hard ticks (Ixodidae) feed from blood only once in each stage; while soft ticks (Argasidae) feed for a short time, many times, but can resist fasting for a long time.

In the current life conditions of the communities the possibilities of ticks infecting humans seem to have increased, or to have been reported in greater numbers, according to documented data (SERRA-FREIRE; MELLO, 2006; SERRA-FREIRE; LEAL, 2009).

Rhipicephalus sanguineus (Latreille, 1806) is a species widely distributed in the world, occurring on five continents. Its primary host is the domestic dog, but it uses other vertebrates as secondary hosts, such as bovines, ovines, and caprines (NORVAL; DAILLECOURT, 1983), and as tertiary or accidental hosts, humans (CLARK et al., 1996; FELZ et al., 1996; VENZAL et al., 2003; NEBREDA-MAYORAL et al., 2004; GUGLIELMONE et al., 2006). Currently, in the face of changes in lifestyle, dogs have a growing contact with humans, exposing both to the movement of zoonosis agents between the two species (LOULY et al., 2006; SERRA-FREIRE; MAGNO, 2009). In Brazil some have been found infected with Rickettsia rickettsii, the agent for Brazilian Spotted Fever, FMB (ROZENTAL et al., 2002) and for Lyme disease (YOSHINARI et al., 1997). Concerning FMB, Serra-Freire and Pinto (2008) have described that in the metropolitan region of Campinas, State of São Paulo, aside from $R$. sanguineus, they found Amblyomma cajennense (Fabricius, 1787), A. dubitatum Neumann, 1899 (= A. cooperi), Anocentor nitens (Neumann, 1897) and Rhipicephalus (Boophilus) microplus (Canestrini, 1887) in a FMB focus area, referring to the risk of infection from those species of ticks; and Perez et al. (2008) considered that in the region of Piracicaba, São Paulo, A. cajennense and $A$. dubitatum could be maintaining the circulation of $R$. rickettsia, found in skunks and capybaras as the amplifying hosts of that microorganism.

Practically there are no bibliographical references about the parasitizing relation between ticks and humans in Northern Brazil, so this project was ideal with its hypothesis concerning the occurrence of parasitism in human hosts by ticks in the State of Pará, aiming to discover the species of ticks that use humans as hosts in one or many phases of their lifecycle.

\section{Material and Methods}

\section{Municipalities approached}

Three municipalities have been sampled, namely: Cachoeira do Arari ( $01^{\circ} 00^{\prime} 41^{\prime \prime} \mathrm{S}$ and $\left.48^{\circ} 57^{\prime} 48^{\prime \prime} \mathrm{W}\right)$, with a $20 \mathrm{~m}$ altitude; Santarém $\left(02^{\circ} 25^{\prime} 30^{\prime \prime} \mathrm{S}\right.$ and $\left.54^{\circ} 42^{\prime} 50^{\prime \prime} \mathrm{W}\right)$, with a $36 \mathrm{~m}$ altitude; and Paragominas ( $3^{\circ} 38^{\prime} 12^{\prime \prime} \mathrm{S}$ and $\left.47^{\circ} 40^{\prime} 55^{\prime \prime} \mathrm{W}\right)$, with a $90 \mathrm{~m}$ altitude (INSTITUTO BRASILEIRO DE GEOGRAFIA E ESTATÍSTICA, 2004).

\section{Making of the survey}

A previously developed questionnaire, identical for all candidates in the three municipalities, contained clear and precise questions on: encountering fixed ticks on the subject's skin, or a relative's skin; ticks walking over pieces of clothing or objects carried next to the body; the presence of skin lesions induced by ticks and the site of these lesions; a history of having or not having physical contact with animals before the finding of ticks; and whether the tick found had been kept, how it was preserved, and whether it was identified. The questions were made by the interviewer, and the answers given by subjects were written down by the interviewer so as to maintain consistency of terms and coherence regarding the body parts mentioned.

Collection of data for the survey lasted two years, between July 2006 and June 2008, with monthly visits to the municipalities, establishing a minimum of 30 interviewees/month in each municipality, integrating 360 people/year/municipality, with a total of 2,160 people in the sample group. No criteria was selected for people to participate in the sample group, so it was independent of gender, age group, occupation, ethnicity, social status, economical power, beliefs, or political, religious or sportive opinions. Conditions to participate were: agreeing to answer the questionnaire, agreeing on being examined in case of having ticks or lesions provoked by ticks, and allowing usage of data for scientific information.

The ticks found and collected were moved to the laboratory for identification. Nymphs and adult specimens were assessed by stereomicroscopy; larvae were clarified and mounted between slide and cover glass, using Hoyer's solution. For species identification, the following publications were used: Robinson (1926), Clifford and Anastos (1960), Aragão and Fonseca (1961), Camicas et al. (1998), Amorim and Serra-Freire (1999), Walker et al. (2000), Horak et al. (2002), Serra-Freire and Mello (2006), Guimarães et al. (2001).

As means of statistical analysis, the ages of the participants were divided in four groups: children - from one to 12 years old; young people - older than 12 and up to 25 years old; adults - older than 25 and up to 60 years old; elders - older than 60 years old. The occupations of the people who comprised the study sample were classified into six groups: salesperson - those who perform activities in trade and commerce (e.g., employees, proprietors, service providers) with a fixed working place; domestic workers and children below 5 years old - those whose work activity was performed at their homes, where they spent most of the day; school and high school student - all of those regularly enrolled in state or private educational institutions, currently at school or high school level; garbage collector, street vendor and unemployed - people responsible for public waste management, engaged in alternative commerce activities, and homeless people with no educational, working, or home bonds; rural worker - group formed by cowboys, foremen, farmers, fishermen, cattle dealers, butchers, tractor drivers, boaters, drivers and assistants for the transportation of live animals, and rural company employees in company housing; tourist - immigrants who do not usually live in the geopolitical spaces, and site visitors with a short stay in the areas. 


\section{Statistics}

To assess the endemic level of tick parasitism in humans the prevalence rates were calculated for a two-year period (period prevalence rate), according to people's occupation, gender and origin. The dominance rate for stages, gender, and tick species were also calculated, as well as the total and species-specific abundance rate. The relative risk (RR) according to human gender and age group for tick parasitism, and the Attributable Risk (AR) for the activity performed in society were also calculated.

The differences between findings considering host characteristics were chi-square tested for adherence ( $\chi^{2}$ test), with a $10 \%$ significance level (SERRA-FREIRE, 2001).

\section{Results and Discussion}

Of the 2,160 interviewed/examined subjects, 1,254 were male $(58.05 \%)$ and the rest 906 female (41.95\%); the prevalence rate was $44.66 \%$ for men and $44.15 \%$ for women. The difference between genders was not significant $(p>0.1)$, consistent with the affirmation by Louly et al. (2006). Regarding the age group of the subjects in the sample, 518 were children, 648 were young people, 756 were adults, and 238 were elders, and prevalence rates varied from 30.12 to $51.32 \%$, conferring to the sample as a whole the prevalence rate of $44.44 \%$ (Table 1). It seems that the age group influences the parasitizing relation between tick and human, since adults have a prevalence value significantly higher than other groups, between teenagers and elders there is no difference in terms of endemicity, and children are the least parasitized. However, the exposure rate of adults, whose rural workload and tasks performed pose greater risk in relation to other age groups, should be considered, mainly among those entering (young people) and leaving (elders) that kind of work, independently of the rural worker's gender. Only among elders did women (prevalence $=52.83 \%$ ) differ significantly from men $($ prevalence $=43.94 \%)(\mathrm{p}<0,1)($ Table 1$)$.

The sample interviewed subjects from six different daily activities that caused them to spend more or less time inside the house, a factor that might have induced the different prevalence rates for tick infestation. Of those in the domestic group there were 52 males and 49 females parasitized by ticks; in the trade work group there were 12 males and 68 females infected; among students, 166 males and 180 females infected by ticks; in the garbage collectors group, two males and six females were parasitized; among the rural workers there were 328 males and 52 females identified with parasites, and in the group of tourists, no male and 45 females were parasitized by ticks. The prevalence rates in these groups varied between 22.86 and $51.35 \%$ (Table 2).

It has been demonstrated that the kind of activity is a conditioning factor for the parasitism of humans by ticks, in which working in a rural environment, or developing teaching activities in a rural area brings more risks of parasitism by ticks. However, staying indoors is not a warranty of absence of risk for tick infestations (SERRA-FREIRE; BORSOI, 2009; SERRA-FREIRE et al., 2009). Also, performing tourism activities in a rural area, with no knowledge of what one might be exposed to, increases the risk for cases of tick infection, as has been found by Serra-Freire and Leal (2009), namely among women (Table 2).

Ninety-seven subjects from Cachoeira do Arari were part of the sample group, and $68.00 \%$ of males and $68.09 \%$ of females were parasitized, most of them rural workers. Another 1,545 people were from Paragominas, with a prevalence rate of 45.54 and $36.97 \%$ for males and females, respectively, with urban and rural inhabitants showing similar proportions. The sample from the municipality of Santarém was composed of 518 people, comprising 82 tourists (15.83\%), 275 rural workers (53.09\%) and 161 people from the urban environment (31.08\%); the prevalence rate for males was $37.36 \%$, and for women $57.55 \%$. The endemic level was larger among the examined rural population (Table 3 ). This proof that being in a rural area in close proximity to animals raises the risk of parasitism by ticks corresponds to evidence by Silva et al. (2007), Louly et al. (2006), and Serra-Freire and Leal (2009).

Cachoeira do Arari, where the economical and social core lies in farming, had the highest prevalence rate, differing significantly from Paragominas and Santarém, which did not differ from each other. It can be assumed that the urbanization level of the populations in the latter two municipalities contributed to the reduction in the relative risk of parasitism (Table 4).

When assessing the host origin together with social occupation in the local society, it has been evidenced that there is a large difference in the occurrence of ixodidosis among the people in the municipalities (Table 4). The calculated relative risk revealed

Table 1. Number of people examined (Examined), of people infected by ticks (Infected), and infection's period prevalence rate (Prevalence) among the components of the human sample studied for natural parasitism by ticks in three municipalities of the State of Pará, according to age group and gender, between July 2006 and June 2008.

\begin{tabular}{|c|c|c|c|c|c|c|c|c|c|}
\hline \multirow{3}{*}{ Gender } & \multicolumn{3}{|c|}{ Man } & \multicolumn{3}{|c|}{ Woman } & \multicolumn{3}{|c|}{ Sum* } \\
\hline & \multirow{2}{*}{$\begin{array}{c}\text { Examined } \\
\left(\mathrm{No}^{\circ}\right)\end{array}$} & \multicolumn{2}{|c|}{ Infected } & \multirow{2}{*}{$\begin{array}{c}\text { Examined } \\
\left(\mathrm{No}^{\circ}\right)\end{array}$} & \multicolumn{2}{|c|}{ Infected } & \multirow{2}{*}{$\begin{array}{c}\text { Examined } \\
\left(\mathrm{No}^{\circ}\right)\end{array}$} & \multirow{2}{*}{$\begin{array}{c}\text { Infected } \\
\left(\mathrm{No}^{\circ}\right)\end{array}$} & \multirow{2}{*}{$\begin{array}{c}\text { Prevalence } \\
(\%)\end{array}$} \\
\hline & & No & $\%$ & & No & $\%$ & & & \\
\hline Children & 254 & 82 & $32.28^{\mathrm{A}}$ & 264 & 74 & $28.03^{\mathrm{A}}$ & 518 & 156 & $30.12^{c}$ \\
\hline Young people & 350 & 154 & $44.00^{\mathrm{A}}$ & 298 & 148 & $49.66^{\mathrm{A}}$ & 648 & 302 & $46.60^{b}$ \\
\hline Adults & 518 & 266 & $51.35^{\mathrm{A}}$ & 238 & 122 & $51.26^{\mathrm{A}}$ & 756 & 396 & $52.38^{a}$ \\
\hline Elders & 132 & 58 & $43.94^{\mathrm{A}}$ & 106 & 56 & $52.83^{\mathrm{B}}$ & 238 & 106 & $44.54^{\mathrm{b}}$ \\
\hline Total & 1,254 & 560 & $44.66^{\mathrm{A}}$ & 906 & 400 & $44.15^{\mathrm{A}}$ & 2,160 & 960 & 44.44 \\
\hline
\end{tabular}

${ }^{*}=$ Equal lower-case letter exponents on the column indicate no significant difference $(\alpha=10 \%)$; different letters indicate significant difference.

** = Equal upper-case letter exponents on the line indicate no significant difference $(\alpha=10 \%)$; different letters indicate significant difference. 
Table 2. Result of the period prevalence rate (PR) of the tick infection, according to the composition of the human (Exam) sample studied for this natural parasitism, in three municipalities of the State of Pará, between July 2006 and June 2008, according to gender and occupational activity.

\begin{tabular}{|c|c|c|c|c|c|c|}
\hline \multirow{2}{*}{ Activity $\quad$ Gender } & \multicolumn{2}{|c|}{ Male** $^{* *}$} & \multicolumn{2}{|c|}{ Female $^{* *}$} & \multicolumn{2}{|c|}{ Sum* } \\
\hline & Exam & PR(\%) & Exam & PR(\%) & Exam & PR(\%) \\
\hline Domestic and underage resident & 150 & $34.67^{\mathrm{A}}$ & 192 & $25.52^{\mathrm{A}}$ & 342 & $29.53^{\mathrm{d}}$ \\
\hline Salesperson & 108 & $11.11^{\mathrm{A}}$ & 96 & $70.83^{\mathrm{B}}$ & 204 & $39.22^{\mathrm{c}}$ \\
\hline School/high school student & 351 & $47.29^{\mathrm{A}}$ & 380 & $47.37^{\mathrm{A}}$ & 731 & $47.33^{\mathrm{ab}}$ \\
\hline Garbage collector and unemployed people & 20 & $10.00^{\mathrm{A}}$ & 15 & $40.00^{\mathrm{B}}$ & 35 & $22.86^{\mathrm{e}}$ \\
\hline Rural worker & 583 & $56.26^{\mathrm{A}}$ & 157 & $33.12^{\mathrm{B}}$ & 740 & $51.35^{\mathrm{a}}$ \\
\hline Tourist & 42 & $0.00^{\mathrm{A}}$ & 66 & $68.18^{\mathrm{B}}$ & 108 & $41.44^{\mathrm{bc}}$ \\
\hline Total & 1,254 & $44.66^{\mathrm{A}}$ & 906 & $44.15^{\mathrm{A}}$ & 2,160 & 44.44 \\
\hline
\end{tabular}

* = Equal lower-case letter exponents on the column of prevalence (PR) indicate no significant difference $(\alpha=10 \%)$; different letters indicate significant difference.

** $=$ Equal upper-case letter exponents on the line, on value of prevalence, indicate no significant difference $(\alpha=10 \%)$; different letters indicate significant difference.

Table 3. Number of examined people (Examined), of people infected by ticks (Infected), and infection's period prevalence rate (PR), among the components of the human sample studied for natural parasitism by ticks in the municipalities of Cachoeira do Arari, Paragominas and Santarém, State of Pará, according to origin and gender, between July 2006 and June 2008.

\begin{tabular}{|c|c|c|c|c|c|c|c|c|c|}
\hline \multirow[t]{3}{*}{ Gender } & \multicolumn{3}{|c|}{ Male } & \multicolumn{3}{|c|}{ Female } & \multicolumn{3}{|c|}{ Sum* } \\
\hline & \multirow{2}{*}{$\begin{array}{c}\text { Examined } \\
\text { № }\end{array}$} & \multicolumn{2}{|c|}{ Infected } & \multirow{2}{*}{$\begin{array}{c}\text { Examined } \\
\text { № }\end{array}$} & \multicolumn{2}{|c|}{ Infected } & \multirow{2}{*}{$\begin{array}{c}\text { Examined } \\
\text { № }\end{array}$} & \multicolumn{2}{|c|}{ Infected } \\
\hline & & № & PR\% & & № & PR\% & & № & PR\% \\
\hline Cachoeira do Arari & 50 & 34 & $68.00^{\mathrm{A}}$ & 47 & 32 & $68.09^{A}$ & 97 & 66 & $68.04^{\mathrm{a}}$ \\
\hline Paragominas & 931 & 424 & $45.54^{\mathrm{A}}$ & 614 & 227 & $36.97^{\mathrm{A}}$ & 1,545 & 651 & $42.14^{b}$ \\
\hline Santarém & 273 & 102 & $37.36^{\mathrm{A}}$ & 245 & 141 & $57.55^{\mathrm{B}}$ & 518 & 243 & $46.91^{b}$ \\
\hline Total & 1,254 & 560 & 44.69 & 906 & 400 & 44.15 & 2,160 & 960 & 44.44 \\
\hline
\end{tabular}

${ }^{*}=$ Equal lower-case letter exponents on the column of prevalence (PR) indicate no significant difference $(\alpha=10 \%)$; different letters indicate significant difference.

** = Equal upper-case letter exponents on the line, on value of prevalence, indicate no significant difference $(\alpha=10 \%)$; different letters indicate significant difference.

a small difference for the chances of parasitism by ticks in humans according to age group ( $R R \leq 0.85)$, but it is almost twice as high for people who work in rural activities $(R R=1.85)$. If rural workers were to practice basic care measures, such as self-inspection every four hours, there would be a reduction of a quarter of cases $(R A=25.93)$. Thus, it is thought that there is a lack of information among these workers, or lack of a follow-up so that these prophylactic measures are routinely practiced.

The tick species identified as parasitizing humans in the three municipalities were: A. cajennense (Fabricius, 1787), Amblyomma aureolatum (Pallas, 1772), Amblyomma brasiliense (Conil 1878), Amblyomma dubitatum (Neumann, 1899), Amblyomma longirostre (Koch, 1844), Amblyomma varium (Koch, 1844), Anocentor nitens (Neumann, 1897), R. sanguineus (Latreille, 1806), and juvenile specimens of the genre Ixodes (Latreille, 1795), in the family Ixodidae; and in the family Argasidae, Ornithodoros talaje (Guérin-Méneville 1849), that being the first time the species was found in Pará (GUIMARĀES et al., 2001; SERRA-FREIRE; MELLO, 2006). An impressive majority of specimens found were adults, possibly due to the easier observation by the subjects parasitized. Males (45.38\%) were dominant, and the least present were the nymphs, with a dominance rate of $8.03 \%$ (Table 5).

The dominance rate of ticks found in humans suggests that for the three municipalities the dominant species is $A$. cajennense (46.88\%), followed by $R$. sanguineus (36.83\%); the less dominant species were $A$. brasiliense and $O$. talaje (Table 5). However, the highest mean intensity of parasitism was that of Ixodes sp. (11.76), basically by larvae (Table 6 ), followed by $A$. varium (8.54), also with a lesser number of larvae. Nonetheless, it is important to notice that the abundance rate shows that $A$. cajennense enjoys higher availability in the environment (2.37 specimens/human), followed by $R$. sanguineus (1.86 specimens/human) for the examined sample (Table 6). Considering the ethology of juvenile stages, the transference of larvae from the environment to the host hardly happens by a single specimen, and for humans as hosts it probably was not different, but adults have an individualized behavior when searching for a host, and only after these are detected are they able to communicate the transference possibility to other adults (SERRA-FREIRE; LEAL, 2009). These different behaviors could explain the higher mean intensity of parasitism by less abundant and less dominant species, as was found in the study.

Although $R$. sanguineus are found in much smaller quantities, Louly et al. (2006) reported having retrieved specimens from humans in the following proportion: $50 \%$ adults, $12.5 \%$ nymphs and $37.5 \%$ larvae, among employees of Veterinary Clinics in Goiânia, Goiás, Brazil, which is similar to the results for Pará, in which adults were more abundant than juveniles.

Adding up all the numbers of cases of human parasitism of all the tick species found (Table 5), the total is about $93 \%$ higher than the indicated number of parasitized humans (Table 1), yet this apparent discrepancy is due to simultaneous infections not referenced under the results by tick species. Simultaneous 
Table 4. Number of people examined (Examined), (infected by ticks) and infection's period prevalence rate (Prevalence), among the components of the human sample studied for natural parasitism by ticks in the municipalities of Cachoeira do Arari, Paragominas and Santarém, State of Pará, according to activity and gender, between July 2006 and June 2008.

\begin{tabular}{|c|c|c|c|c|c|c|c|}
\hline \multirow[t]{2}{*}{ Origin } & \multirow{2}{*}{ Gender } & \multicolumn{2}{|c|}{ Male } & \multicolumn{2}{|c|}{ Female } & \multicolumn{2}{|c|}{ Sum* } \\
\hline & & $\begin{array}{c}\text { Examined } \\
\text { № }\end{array}$ & $\begin{array}{c}\text { Prevalence } \\
\%\end{array}$ & $\begin{array}{c}\text { Examined } \\
\text { № }\end{array}$ & $\begin{array}{c}\text { Prevalence } \\
\%\end{array}$ & $\begin{array}{c}\text { Examined } \\
\text { № }\end{array}$ & $\begin{array}{c}\text { Prevalence } \\
\%\end{array}$ \\
\hline \multirow{7}{*}{$\begin{array}{l}\text { Cachoeira do } \\
\text { Arari }\end{array}$} & Domestic and underage resident & 5 & (2) 40.00 & 7 & (3) 42.86 & 12 & 41.67 \\
\hline & Salesperson & 3 & (1)33.33 & 2 & (1) 50.00 & 5 & 60.00 \\
\hline & School/high school student & 8 & $(5) 62.5$ & 7 & $5(4) 57.14$ & 15 & 60.00 \\
\hline & Garbage collector and unemployed people & 1 & $(0) 0.00$ & 2 & $(1) 50.00$ & 3 & 33.33 \\
\hline & Rural worker & 31 & $(26) 83.87$ & 27 & $(22) 81.48$ & 58 & 82.76 \\
\hline & Tourist & 2 & $(0) 0.00$ & 2 & $(0) 0.00$ & 4 & 0.00 \\
\hline & Sub-total 1 & 50 & $(34) 68.00$ & 47 & (32)68.09 & 97 & $68.04^{a}$ \\
\hline \multirow[t]{7}{*}{ Paragominas } & Domestic and underage resident & 75 & $(39) 52.00$ & 119 & $(37) 31.09$ & 194 & 39.18 \\
\hline & Salesperson & 56 & (6) 10.71 & 57 & $(32) 56.14$ & 113 & 38.05 \\
\hline & School/high school student & 313 & $(147) 46.96$ & 305 & $(133) 43.61$ & 618 & 34.30 \\
\hline & Garbage collector and unemployed people & 10 & (1) 10.00 & 8 & $(4) 50.00$ & 18 & 61.11 \\
\hline & Rural worker & 469 & $(231) 49.25$ & 111 & (12) 10.81 & 580 & 51.72 \\
\hline & Tourist & 8 & $(0) 0.00$ & 14 & (9)64.29 & 22 & 40.91 \\
\hline & Sub-total 2 & 931 & $(424) 45.54$ & 614 & $(227) 36.97$ & 1,545 & $42.14^{\mathrm{b}}$ \\
\hline \multirow[t]{7}{*}{ Santarem } & Domestic and underage resident & 70 & $(11) 15.71$ & 66 & (9) 13.64 & 136 & 14.71 \\
\hline & Salesperson & 49 & (5) 10.20 & 37 & $(35) 94.59$ & 86 & 46.51 \\
\hline & School/high school student & 30 & $(14) 46.67$ & 68 & $(42) 61.76$ & 98 & 57.14 \\
\hline & Garbage collector and unemployed people & 9 & (1) 11.11 & 5 & (1) 20.00 & 14 & 14.29 \\
\hline & Rural worker & 83 & $(71) 85.54$ & 19 & (18)94.74 & 102 & 24.51 \\
\hline & Tourist & 32 & $(0) 0.00$ & 50 & $(36) 72.00$ & 82 & 43.90 \\
\hline & Sub-total 3 & 273 & (102)37.36 & 245 & (141)57.55 & 518 & $46.91^{\mathrm{b}}$ \\
\hline Total & & 1,254 & $44.66^{\mathrm{A}}$ & 906 & $44.15^{\mathrm{A}}$ & 2,160 & 44.44 \\
\hline
\end{tabular}

* = Equal lower-case letter exponents on the column of prevalence indicate no significant difference $(\alpha=10 \%)$; different letters indicate significant difference.

Table 5. Species of the 10,916 ticks found parasitizing humans in population samples studied for natural parasitism by ticks in the municipalities of Cachoeira do Arari, Paragominas and Santarém, State of Pará, between July 2006 and June 2008, with the indicative of dominance rate (DR).

\begin{tabular}{|c|c|c|c|c|c|c|c|c|c|c|}
\hline \multirow{2}{*}{ Species $^{\text {Stage }}$} & \multicolumn{2}{|c|}{ Larvae } & \multicolumn{2}{|c|}{ Nymphs } & \multicolumn{2}{|c|}{ Males } & \multicolumn{2}{|c|}{ Females } & \multicolumn{2}{|c|}{ Sum specie } \\
\hline & No & $\mathrm{DR}^{1}(\%)$ & No & DR(\%) & No & DR(\%) & No & DR(\%) & No & DR(\%) \\
\hline Amblyomma varium & 72 & 0.66 & 14 & 0.13 & 18 & 0.16 & 7 & 0.06 & 111 & 1.02 \\
\hline A. cajennense & 286 & 2.62 & 450 & 4.11 & 2,487 & 22.79 & 1,895 & 17.37 & 5,118 & 46.88 \\
\hline A. aureolatum & 12 & 0.11 & 26 & 0.24 & 17 & 0.16 & 10 & 0.09 & 65 & 0.60 \\
\hline A. brasiliense & 2 & 0.02 & 0 & 0 & 11 & 0.10 & 9 & 0.08 & 22 & 0.20 \\
\hline A. dubitatum & 14 & 0.13 & 39 & 0.36 & 178 & 1.63 & 146 & 1.34 & 377 & 3.45 \\
\hline A. longirostre & 154 & 1.41 & 53 & 0.49 & 49 & 0.45 & 44 & 0.40 & 300 & 2.75 \\
\hline Anocentor nitens & 13 & 0.12 & 29 & 0.27 & 238 & 2.18 & 201 & 1.84 & 481 & 4.41 \\
\hline R. sanguineus & 97 & 0.89 & 224 & 2.05 & 1,946 & 17.83 & 1,753 & 16.06 & 4,020 & 36.83 \\
\hline Ixodes sp. & 358 & 3.27 & 42 & 0.38 & 0 & 0 & 0 & 0 & 400 & 3.66 \\
\hline Ornithodorus talaje & 0 & 0 & 0 & 0 & 9 & 0.08 & 13 & 0.12 & 22 & 0.20 \\
\hline Total & 1,008 & 9.23 & 877 & 8.03 & 4,953 & 45.38 & 4,078 & 37.36 & 10,916 & 100.00 \\
\hline
\end{tabular}

${ }^{1}$ Dominance rate $=($ number of tick stages for each species $\times 100)$ : sum of all ticks.

parasitism among species happened namely with $A$. cajennense and $R$. sanguineus, with cases of two and three species on the same host. In Table 6 are presented the data on the number of subjects parasitized by ticks, not counting the repetition of parasitism cases on the same subject, and not considering cases in which the subject mentioned having observed more than once the presence of ticks on their body, when the specimens have not been seen by the researchers. That is because it could not be confirmed
(SERRA-FREIRE, 2009) whether all the subjects who declared the presence of ticks were in fact parasitized by them, since, in some of the cases the parasites presented were actually lice (Insecta, Phthiraptera, Anoplura).

The $A$. cajennense is a multiple-host species with a heteroxenous vital cycle, which has been frequently reported parasitizing humans (SERRA-FREIRE; MELLO 2006). It has toxicophore power (SERRA-FREIRE, 1983), and is a vector of many pathogens, 
Table 6. Dominance rate (DR), abundance rate (AR), mean intensity of parasitism (MIP), for the species among the 10,916 ticks found in 2,160 humans examined in the population sample studied for natural parasitism by ticks in the municipalities of Cachoeira do Arari, Paragominas and Santarém, State of Pará, between July 2006 and June 2008.

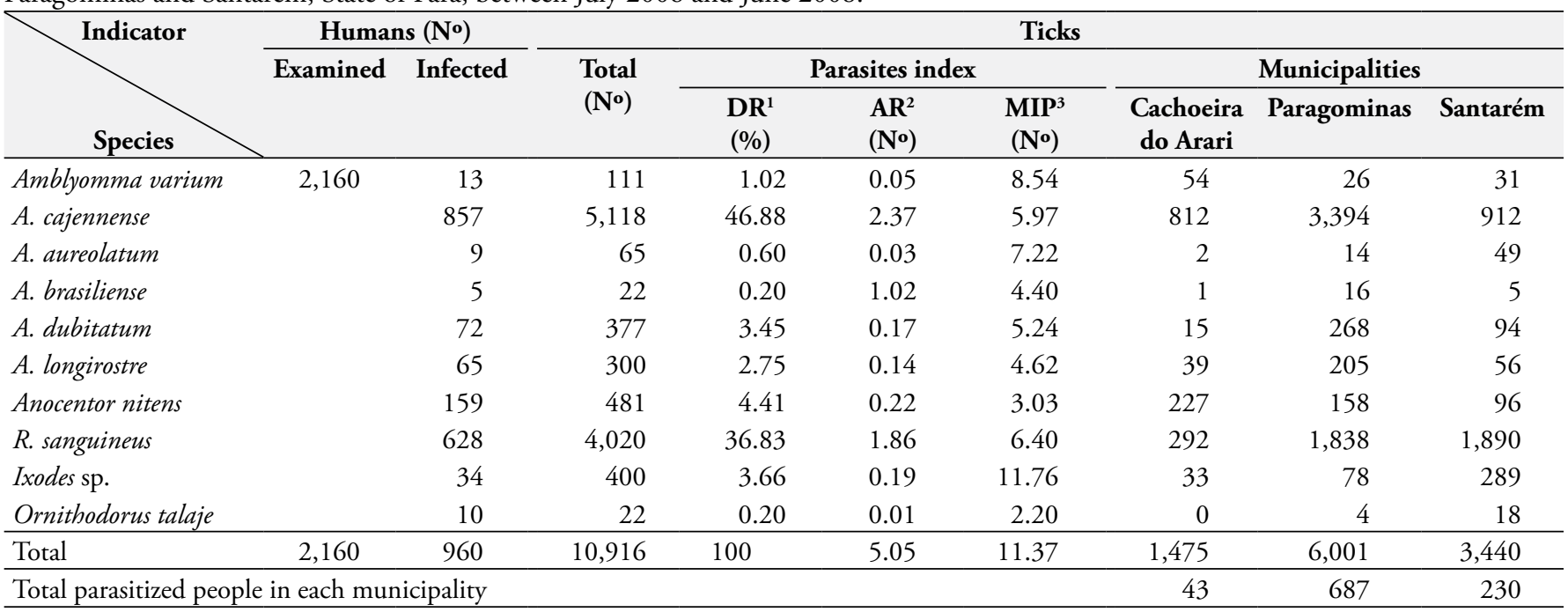

${ }^{1} \mathrm{DR}=$ dominance rate; ${ }^{2} \mathrm{AR}=$ Abundance rate; ${ }^{3} \mathrm{MIP}=$ Mean intensity of parasitism.

being the most present one in Cachoeira do Arari and Paragominas, followed by $R$. sanguineus, in the same municipalities. However, in Santarém $R$. sanguineus was the dominant species in terms of number of cases, followed by $A$. cajennense (Table 6). Consider that Cachoeira do Arari is fundamentally rural, Paragominas has a large rural activity but is largely an urban area, and Santarém is more urban, although there is still a lot of rural activity. The third most present species had no correspondence among the three municipalities, since for Cachoeira do Arari it was $A$. nitens, for Paragominas it was $A$. dubitatum, and for Santarém it was Ixodes sp.; there is no data in the literature that points to this result, but the comparison between municipalities shows that in places where human activity is more urban, human parasitism by ticks is dominated by $R$. sanguineus, and where it is more rural dominance is by $A$. cajennense.

Considering that these two species are acknowledged as rickettsia vectors, with an emphasis on Brazilian Spotted Fever (SERRA-FREIRE; PINTO, 2008); that ticks of the Ixodes genus keep the $R$. rickettsii in circulation among sylvatic synanthrope animals like opossums; that $R$. sanguineus keeps FMB enzootic among dogs in an urban environment (LEMOS et al., 1997); that $A$. cajennense is responsible for FMB enzootics in rural and peri-urban environments (PEREZ et al., 2008), influenced by its seasonal activity (LEMOS et al., 1997); that $A$. dubitatum was found keeping those rickettsias in circulation in fields and sylvatic environments (LEMOS et al., 1996); and that all those species parasitize humans in Pará; they are an indication of risk for the establishment of these diseases in humans in the state.

It is known that the dog is the preferential host for $R$. sanguineus (FREITAS et al., 1978). However, according to Hoogstraal and Aeschlimann (1982), the discriminatory sense of ticks is weakened or even lost when they are dislodged during the feeding process, which might explain why the people in the study group observed the presence of ticks after contact with dogs and horses. $R$. sanguineus is referred to as a human parasite in many countries, such as: the United States (CLARK et al., 1996; FELZ et al., 1996), Spain (NEBREDA-MAYORAL et al., 2004) and
Uruguay (VENZAL et al., 2003), but in Brazil Louly et al. (2006) e Dantas-Torres et al. (2006) registered the first finding of a parasitizing relation between $R$. sanguineus and humans, in Goiás and Pernambuco, respectively.

Most studies on the prevalence of ixodides in humans in Brazil were carried out in rural or periurban regions and the only species found was Amblyomma cajennense (LEMOS et al., 1997; LABRUNA; PEREIRA, 2001). But parasitism by $R$. sanguineus in humans assumed special importance when it was considered that the results of Rozental et al. (2002) identified by direct immunofluorescence the presence of the spotted fever agent, $R$. rickettsii, in this species of tick, which may imply on the maintance of that rickettsia in nature, and even its transmission to man. Another important consideration was the result of the survey on the profile of Lyme's disease in Brazil, when Yoshinari et al. (1997) examined the main species of ticks present in an occurrence region for that disease and $R$. sanguineus was identified as its potential vector.

\section{Conclusion}

In the Pará state there is frequent human parasitism by $A$. cajennense and $R$. sanguineus, in low endemicity levels. Nine species of hard ticks (Ixodidae Family) and one of soft ticks (Argasidae Family) parasitizes humans in three regions of the state. There is no statistically acceptable difference between parasitism levels in males and females, and between age groups; being a rural worker doubles the chances of parasitism by ticks. The occurrence of Ornithodorus talaje is registered in Pará.

\section{References}

AMORIM, M.; SERRA-FREIRE, N. M. Chave dicotômica para identificação de larvas de algumas espécies do gênero Amblyomma Koch, 1844 (Acari: Ixodidae). Entomologia y Vectores, v. 6, n. 1, p. 75-90, 1999. 
ARAGÃO, H.; FONSECA, F. Notas de Ixodologia VIII: lista e chave para os representantes da fauna ixodológica brasileira. Memorias do Instituto Oswaldo Cruz, v. 59, n. 2, p. 115-129, 1961.

CAMICAS, J. L. et al. The ticks of the world: nomenclature, described stages, Hosts, Distribution (Acaridida, Ixodida). Paris: Orstom, 1998. p. 233.

CLARK, K. L. et al. Ticks removed from dogs and animal care personnel in Orangeburg County, South Carolina. Journal of Agromedicine, v. 3, n. 4, p. 44-55, 1996.

CLIFFORD, C. M.; ANASTOS, G. The use of chaetotaxy in the identification of larval ticks (Acarina: Ixodidae). Journal of Parasitology, v. 46, n. 5, p. 567-578, 1960.

DANTAS-TORRES, F; FIGUEREDO, L. A.; BRANDÃO-FILHO, S. P. Rhipicephalus sanguineus (Acari: Ixodidae), the Brown dog tick, parasitizing humans in Brazil. Revista da Sociedade Brasileira de Medicina Tropical, v. 39, n. 1, p. 64-67, 2006.

FELZ, M. W.; DURDEN, L. A.; OLIVER, J. H. Ticks parasitizing humans in Georgia and South Carolina. Journal of Parasitology, v. 82, n. 3, p. 505-508, 1996.

FREITAS, M. G. et al. Entomologia e acarologia médica e veterinária. Belo Horizonte: Rabelo \& Brasil, 1978. p. 396.

GUGLIELMONE, A. A. et al. Diversidade e importância de carrapatos na sanidade animal. In: BARROS-BATTESTI, D. M.; ARZUA, M.; BECHARA, G. H. Carrapatos de importância Médico-veterinária da regiáo neotropical: um guia ilustrado para identificação de espécies. São Paulo: Vox/ICTTD-3/Butantan, 2006. p. 223.

GUIMARÃES, J. H.; TUCCI, E. C.; BARROS-BATTESTI, D. M. Ectoparasitos de importância veterinária. São Paulo: Plêiade/Fapesp, 2001. 308 p.

HOOGSTRAAL, H.; AESCHLIMANN, A. Tick host specificity. Bulletin de la Societe Entomologique Suisse, v. 55, p. 5-32, 1982.

HORAK, I. G.; CAMICAS, J. L.; KEIRANS, J. E. The Argasidae, Ixodidae e Nuttalliellidae (Acari: Ixodida): a world list of valid tick names. Experimental \& Applied Acarology, v. 28, n. 1-4, p. 27-54, 2002.

INSTITUTO BRASILEIRO DE GEOGRAFIA E ESTATÍSTICA IBGE. Produçáo da Pecuária Municipal. Belém, 2004. p. 1-32.

KJEMTRUP, A. M.; CONRAD, P. A. Human babesiosis: an emerging tick-borne disease. International Journal for Parasitology, v. 30, n. 12-13, p. 1323-1337, 2000.

LABRUNA, M. B.; PEREIRA; M. C. Febre maculosa: aspectos clínicoepidemiológicos. Clínica Veterinária, v. 12, p. 19-23, 2001.

LEMOS, E. R. S. et al. Primary isolation of spotted fever group rickettsiae from Amblyomma cooperi collected from Hydrochaeris hydrochaeris in Brazil. Memorias do Instituto Oswaldo Cruz, v. 91, n. 3, p. 273-277, 1996.

LEMOS, E. R. S. et al. Rickettsiae-infected ticks in an endemic area of spotted fever in the State of Minas Gerais, Brazil. Memorias do Instituto Oswaldo Cruz, v. 92, n.4, p. 477-481, 1997.

LOULY, C. C. B. et al. Ocorrência de Rhipicephalus sanguineus em trabalhadores de Clínicas Veterinárias e Canis, no Município de Goiânia, GO. Ciencia Animal Brasileira, v. 7, n. 1, p. 103-106, 2006.

NEBREDA-MAYORAL, T. et al. Detection of antibodies to tick salivary antigens among patients from a region of Spain. European Journal of Epidemiology, v. 19, n. 1, p. 79-83, 2004.
NORVAL, R. A. I.; DAILLECOURT, T. The ticks of Zimbabwe. VI. The Rhipicephalus sanguineus group. Zimbabwe Veterinary Journal, v. 13 , p. 38-46, 1983.

PEREZ, C. A. et al. Carrapatos do gênero Amblyomma (Acari, Ixodidae) e suas relaçóes com os hospedeiros em área endêmica para Febre Maculosa no Estado de Sáo Paulo. Revista Brasileira de Parasitologia Veterinária, v. 17, n. 4 , p. $210-217,2008$.

ROBINSON, L. E. Ticks. A monograph of the Ixodoidea: Part IV - The genus Amblyomma. (the first part of volume II). Cambridge: University Press, 1926. p. 302.

ROZENTAL, T. et al. Evidence of spotted fever group rickettsiae in state of Rio de Janeiro, Brazil. Revista da Sociedade Brasileira de Medicina Tropical, v. 44, n. 3, p. 155-158, 2002.

SERRA-FrEIRE, N. M. Tick paralysis in Brazil. Tropical Animal Health and Production, v. 15, n. 2, p. 124-126, 1983.

SERRA-FREIRE, N. M. Planejamento e análise de pesquisas parasitológicas. Niterói: EdUFF, 2001. p. 199.

SERRA-FREIRE, N. M. Parasitismo humano por carrapatos: a necessidade de transformação do paradigma diagnóstico. Revista Vetores \& Pragas, v. 12, n. 22, p. 23-27, 2009.

SERRA-FREIRE, N. M.; AMORIM, M.; SILVA, N. P. Risco de Infecção Humana por Rhipicephalus sanguineus Latreille, 1806 (Acari, Ixodidae) em Ambiente Domiciliar na cidade do Rio de Janeiro, RJ, Brasil. Revista Brasileira de Medicina Veterinaria, v. 31, n. 4, 2009.

SERRA-FREIRE, N. M.; BORSOI, A. B. P. Malformação em teleógina de Rhipicephalus sanguineus recolhida em ambiente intradomiciliar, no Rio de Janeiro, RJ. Revista Brasileira de Parasitologia Veterinária, v. 18 , n. 2 , p. $53-56,2009$.

SERRA-FREIRE, N. M.; LEAL, A. Vertical dispersion and strategy of transference of Amblyomma triste Koch, 1844 (Acari: Ixodidae) in the nature, of the vegetation for human host. Revista Brasileira de Medicina Veterinaria, v. 31, n. 2, p. 76-81, 2009.

SERRA-FREIRE, N. M.; MAGNO, I. Avaliação sobre a presença de ácaros nas condiçôes microclimáticas do aeroporto Santos Dumont em relação arquitetura, e de carrapatos no entorno. Revista Brasileira de Medicina Veterinaria, v. 31, n. 2, p. 85-91, 2009.

SERRA-FREIRE, N. M.; MELLO, R. P. Entomologia e acarologia na medicina veterinária. Rio de Janeiro: L.F. Livros, 2006. p. 199.

SERRA-FREIRE, N. M.; PINTO, C. Vetores de riquétsias do Grupo Febre Maculosa na região metropolitana de Campinas, Estado de São Paulo: prevalência e risco de transmissão. Revista Brasileira de Medicina Veterinaria, v. 30, n. 4, p. 254-259, 2008.

SILVA, B. S. F. et al. Observação e caracterização da altura de carrapatos em arbustos do parque natural municipal de Porto Velho, Amazônia Ocidental, RO. Saber Científico, v. 1, n. 1, p. 118-131, 2007.

VENZAL, J. M. et al. Ticks (Ixodida: Ixodidae) parasitising humans in Uruguay. Annals of Tropical Medicine and Parasitology, v. 97, n. 7, p. 769-772, 2003.

WALKER, J. B.; KEIRANS, J. E.; HORAK, I. G. The genus Rhipicephalus (Acari: Ixodidae). A guide to the Brown ticks of the world. London: Cambridge University Press, 2000. p. 643.

YOSHINARI, N. H. et al. Perfil da borreliose de Lyme no Brasil. Revista do Hospital das Clínicas, v. 52, p. 111-117, 1997. 